\title{
Iktiosis Lamelar pada Anak dengan Riwayat Bayi Kolodion
}

\author{
Suraiyah", Soepardi Soedibyo*, Siti Aisah Boediardja* \\ *Pediatri Rawat Jalan, Departemen Ilmu Kesehatan Anak, Fakultas Kedokteran Universitas \\ Indonesia, Jakarta \\ **Departemen Kulit dan Kelamin, Departemen Ilmu Kesehatan Anak, Fakultas Kedokteran \\ Universitas Indonesia, Jakarta
}

\begin{abstract}
Abstrak. Seorang anak perempuan, usia 3 tahun dengan keluhan kulit yang mengelupas terus menerus (rujukan dari bagian kulit dan kelamin, untuk mengevaluasi adakah kelainan metabolik bawaan). Adanya riwayat bayi lahir dengan kulit terbungkus plastik, mengkilap, transparan disertai kelainan bentuk daun telinga yang kecil dan kelopak mata terangkat keatas. Tidak terdapat konsanguitas dalam keluarga. Kulit pada seluruh tubuh mengelupas secara kontinyu, gatal dan berbau tidak sedap. Luka/ lecet akibat bekas garukan pada kulit sehingga terbentuk jaringan parut tebal dan berakibat terjadinya kontraktur pada jarijari tangan. Pada pemeriksaan fisis ditemukan kulit kepala yang tebal berkeropeng, ektropion, alopesia sikatrik dengan bentuk mulut normal. Pada kedua telinga didapatkan hipoplasi kartilago aurikula. Pada kulit tampak skuama kasar, lebar, berwarna kecoklatan dengan eritroderma ringan. Pemeriksaan laboratorium didapatkan hemoglobin $11,4 \mathrm{~g} / \mathrm{dL}$, leukosit $10.100 / \mu \mathrm{L}$, tombosit $431.000 / \mu \mathrm{L}$. Biopsi kulit didapatkan hiperkeratosis, sumbatan keratin, akantosis dan papilomatosis ringan disertai pelebaran pembuluh darah dan serbukan sel radang ringan pada dermis. Ikltiosis lamelar adalah genodermatosis yang biasanya diturunkan secara resesif autosomal, adanya konsanguitas meningkatkan risiko terjadinya kasus ini.. Anamnesis dan penilaian klinis sangat penting dalam menegakkan diagnosis tetapi diagnosis pasti ditegakkan berdasarkan biopsi kulit (Sari Pediatri 2007; 9(10):32-38).
\end{abstract}

Kata kunci: iktiosis lamelar, bayi kolodion, autosomal resesif genodermatosis.

\footnotetext{
Alamat korespondensi

Dr. Soepardi Soedibyo, SpA(K).

Pediatri Rawat Jalan Dep. Ilmu Kesehatan Anak FKUI. Departemen Ilmu Kesehatan Anak FKUI-RSCM. Jl. Diponegoro 71, Jakarta 10430.

Telepon: 021-3915179. Fax: 021-390 7743.
}

$\mathrm{I}$ ktiosis lamelar (IL) merupakan penyakit kulit yang diturunkan secara genetik (genoder matosis), ditandai adanya gangguan kornifikasi epidermis karena mutasi gen TGM1. Kata iktiosis berasal dari bahasa Yunani ichthys yang berarti ikan, untuk menggambarkan kelainan kulit seperti sisik ikan. ${ }^{1,2}$ Kelainan ini merupakan bagian dari autosomal 
recessive congenital ichthyosis (ARCI). ${ }^{4}$ Awitan penyakit dapat muncul sejak lahir maupun beberapa tahun kemudian, dan dapat hanya terbatas pada kulit maupun disertai kelainan sistem organ lain. ${ }^{2}$ Diagnosis IL ditegakkan berdasarkan gambaran klinis, tetapi pada kasus yang meragukan perlu dilakukan biopsi kulit. ${ }^{4}$ Terapi IL bersifat suportif untuk menjaga kelembaban kulit dengan pemberian emolien yang mengandung bahan keratolitik sedangkan pada mata lubrikasi dan pencegahan iritasi. ${ }^{2}$ Kemajuan di bidang genetika molekular penting dalam upaya melakukan diagnostik prenatal dan terapi definitif. ${ }^{5}$

Seorang anak perempuan, $\mathrm{M}$, usia 3 tahun datang ke Poliklinik Umum Departemen Ilmu Kesehatan Anak (IKA) RS Dr. Ciptomangunkusumo Jakarta pada

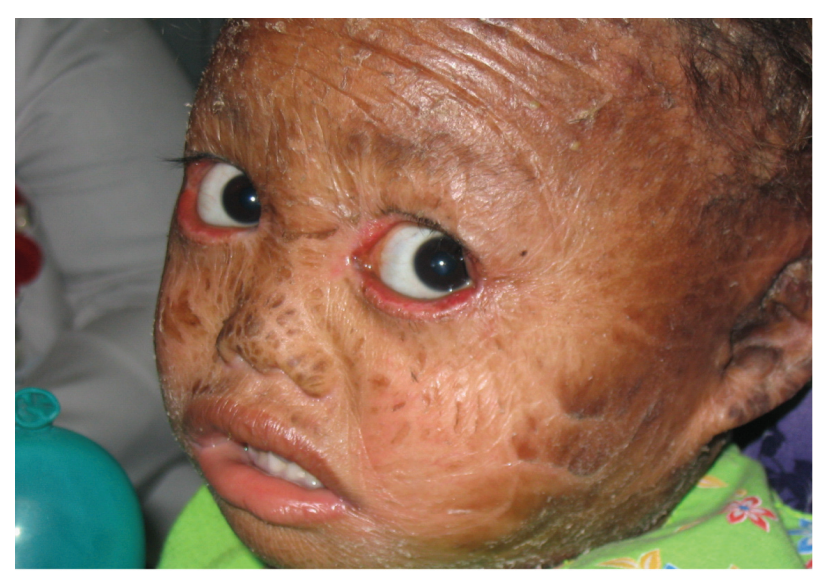

Gambar 1. Kulit dengan skuama tebal, kecoklatan, mata ektropion.

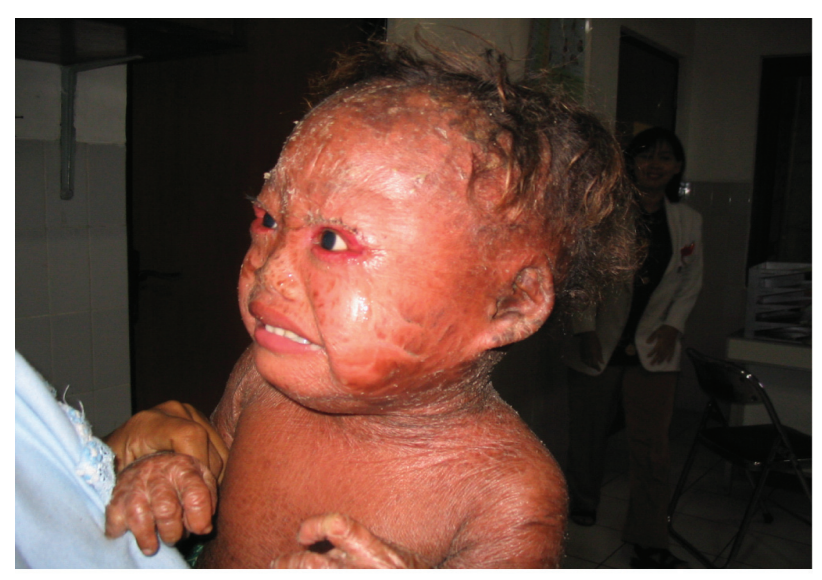

Gambar 2. Jari-jari tangan kontraktur, hipoplasi kartilago aurikula. tanggal 6 April 2006 atas rujukan Departemen Kulit dan Kelamin RS Dr. Ciptomangunkusumo dengan diagnosis kerja iktosis lamelar, untuk mencari adakah kelainan sistemik.

Dari alloanamnesis dari ibu pasien diketahui bahwa selama kehamilan ibu sehat dan memeriksakan kehamilannya secara teratur ke bidan. Ibu hanya minum vitamin untuk kehamilan dan tidak pantang makanan tertentu. Pasien lahir kurang bulan (36 minggu), di rumah, ditolong bidan, langsung menangis, tidak biru ataupun sesak, berat lahir 2800 gram dan panjang lahir tidak diketahui. Sejak lahir kulit pasien seperti dibungkus plastik, mengkilap, transparan disertai kelainan bentuk daun telinga yang kecil dan kelopak mata terangkat keatas.

Pasien dirawat di RS N selama 12 hari dan membran yang melapisi kulit berangsur-angsur mengelupas. Selama perawatan tersebut orangtua tidak memperoleh keterangan yang jelas mengenai kelainan kulit pada anaknya dan karena keterbatasan dana, pasien dibawa pulang atas permintaan orangtua. Tidak didapatkan riwayat kuning, kejang maupun sakit berat lainnya.

Kulit pada seluruh tubuh mengelupas secara kontinyu, terasa gatal (sering menggaruk kulitnya) dan berbau tidak sedap. Pasien sering menggaruk kulitnya terutama pada jari-jari tangan sampai luka/lecet sehingga terbentuk jaringan parut yang tebal antara jari IV - V tangan kanan sehingga jari $\mathrm{V}$ tertekuk (kontraktur). Orangtua pasien berniat membawa anaknya ke dokter kulit tetapi tertunda karena masalah biaya. Setelah mendapat bantuan dana untuk pengobatan, pasien dibawa ke dokter kulit dan kemudian dirujuk ke Departemen Kulit dan Kelamin RSCM dengan diagnosis kerja iktiosis lamelar, untuk mencari adakah kelainan sistemik.

Pasien dapat tengkurap pada usia 4 bulan, duduk usia 10 bulan dan baru dapat berjalan setelah usia 18 bulan. Perkembangan mental pasien terkesan normal. Pergaulan dengan teman-temannya cukup baik meskipun terkadang pasien merasa rendah diri karena penyakit yang dideritanya. Pasien tidak pernah mendapat imunisasi dasar karena bidan tidak berani melakukan imunisasi sehubungan dengan kelainan yang diderita pasien. Air susu ibu (ASI) diberikan sejak lahir sampai sekarang. Setelah usia 4 bulan pasien mendapat makanan lunak dan pada usia 1 tahun diberikan makanan padat (makanan keluarga).

Pasien adalah anak tunggal, ayah pasien berusia 27 tahun, suku Jawa pendidikan SD, bekerja sebagai 
buruh tani. Ibu berusia 22 tahun, suku Jawa, pendidikan SMP, ibu rumah tangga. Riwayat atopi dan keganasan dalam keluarga disangkal. Tidak ada konsanguinitas antara ayah dan ibu, tidak ada anggota keluarga yang menderita penyakit seperti pasien. Pola pewarisan genetik pada keluarga pasien tertera pada Gambar 3.

Pada pemeriksaan fisis didapatkan anak sadar, tidak sesak, tidak sianosis. Berat badan (BB) $10 \mathrm{~kg}\left(<\mathrm{P}_{3}\right.$ CDC- tahun 2000), tinggi badan (TB) $84 \mathrm{~cm}\left(<\mathrm{P}_{3}\right.$ CDC tahun 2000). Status antropometri: berat badan terhadap umur $72 \%$; tinggi badan terhadap umur $88,4 \%$; berat badan terhadap tinggi badan aktual $84,7 \%$ (kurang). Laju denyut nadi sama dengan laju denyut jantung $100 \mathrm{kali} / \mathrm{menit}$, teratur, isi cukup, laju pernapasan $24 \mathrm{x} /$ menit, teratur, kedalaman cukup, suhu $36,6^{\circ} \mathrm{C}$ (aksila).

Pada pemeriksaan kepala didapatkan bentuk kepala yang normal, rambut kecoklatan, tidak mudah dicabut, tampak kulit kepala yang tebal berkeropeng. Wajah tidak terlihat dismorfik, terdapat ektropion dan alopesia sikatrik dengan bentuk mulut normal. Konjungtiva mata tidak pucat, sklera tidak ikterik, gerak bola mata normal. Pada kedua telinga didapatkan hipoplasi kartilago aurikula (Gambar 1). Pada pemeriksaan hidung dan tenggorok tidak didapatkan kelainan. Pada rongga mulut tampak gigi-geligi dengan bentuk dan susunan gigi tampak rapi. Bunyi jantung I dan II normal, tidak terdapat bising maupun irama derap. Bunyi napas vesikular, tidak terdengar ronki, maupun mengi. Perut datar, perabaan lemas, turgor kulit cukup, hati dan limpa tidak teraba, bising usus normal. Pada genitalia tidak didapatkan kelainan. Alat gerak teraba hangat dengan perfusi perifer baik, refleks fisiologis normal, kekuatan motorik normal, terdapat kontraktur pada jari ke $\mathrm{V}$ tangan kanan (Gambar 2). Kelainan kulit dijumpai pada seluruh tubuh berupa skuama kasar, lebar, berwarna kecoklatan dengan eritroderma ringan. (Gambar 1)

Pemeriksaan darah perifer lengkap (6 April 2006) menunjukkan hemoglobin $11,4 \mathrm{~g} / \mathrm{dL}$, hematokrit $32,8 \%$, eritrosit $4.170 .000 / \mu \mathrm{L}$, mean corpuscular volume (MCV) 78,6 fL (76 - 96), mean corpuscular hemoglobin (MCH) 27,3 pg (27 - 32), mean corpuscular hemoglobin concentration (MCHC)

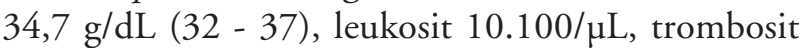
$431.000 / \mu \mathrm{L}$, hitung jenis (\%) basofil 0 , eosinofil 0 , batang 0 , segmen 59, limfosit 40, monosit 1 . Gambaran darah tepi menunjukkan eritrosit dengan bentuk normokrom normositer. Hasil biopsi kulit didapatkan adanya hiperkeratosis, sumbatan keratin, akantosis dan papilomatosis ringan disertai pelebaran pembuluh darah dan adanya serbukan sel radang ringan pada daerah dermis, gambaran ini sesuai dengan iktiosis lamelar. Diagnosis kerja saat itu adalah iktiosis lamelar dan gizi kurang.

Pasien mendapat makanan biasa 1200 kalori dan makanan cair 4 x $150 \mathrm{~mL}$, pemeriksaan analisis gas darah (AGD), elektrolit, albumin, SGOT, SGPT, ureum, kreatinin dan urinalisis. Hasil pemeriksaan

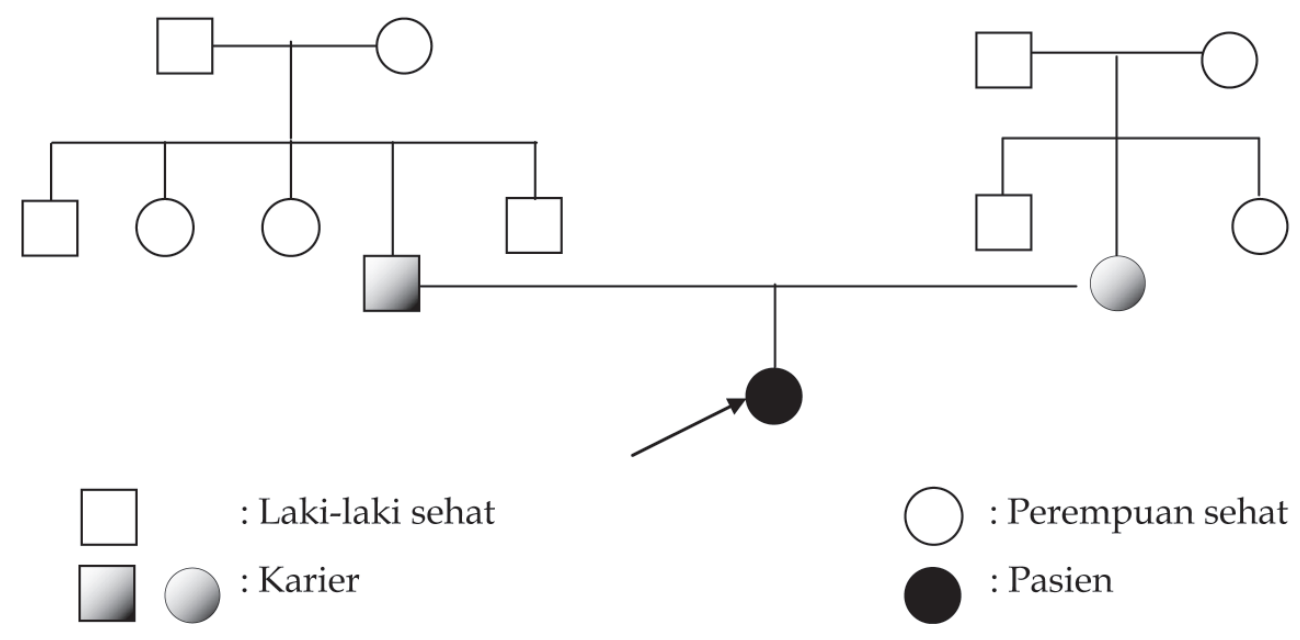

Gambar 3. Silsilah keluarga pasien 
AGD didapatkan $\mathrm{pH} 7,390, \mathrm{pCO}_{2} 28,2 \mathrm{mmHg}, \mathrm{pO} 2$ $87,7 \mathrm{mmHg}, \mathrm{HCO} 317 \mathrm{mEq} / \mathrm{L}, \mathrm{BE}-5,7 \mathrm{mEq} / \mathrm{L}$, saturasi oksigen $96,8 \%$, elektrolit natrium $136 \mathrm{mEq} /$ $\mathrm{L}$, kalium 4,7 mEq/L, klorida $103 \mathrm{mEq} / \mathrm{L}$, kalsium $1,07 \mathrm{mEq} / \mathrm{L}$, albumin 3,92 g/dL, SGOT $32 \mathrm{U} / \mathrm{L}$, SGPT $17 \mathrm{U} / \mathrm{L}$, ureum $18 \mathrm{mg} / \mathrm{dL}$, kreatinin $0,78 \mathrm{mg} /$ dL. Hasil urinalisis didapatkan $\mathrm{pH} 6,8$, berat jenis 1,015 , protein (-), reduksi (-), epitel (+), lekosit $0-1 /$ LPB, eritrosit 0-1/LPB, kristal (-). Dari semua pemeriksaan tersebut disimpulkan hasilnya masih dalam batas normal.

Obat-obatan topikal yang didapat dari Departemen Kulit dan Kelamin berupa emolien yang mengandung bahan keratolitik seperti urea $10 \%$, asam laktat dan asam glikolat serta sabun Oilum ${ }^{\circledR}$ dilanjutkan. Pasien dikonsultasikan ke Departemen Mata karena adanya ektropion yang menyebabkan pasien sulit dalam menutup mata. Hasil konsultasi didapatkan adanya sikatrik pada mata kiri tetapi mata kanan dalam batas normal. Tata laksana yang diberikan berupa preparat Cendo Lyteers dan Oculotect gelâ diberikan pada kedua mata, berfungsi sebagai emolien, lubrikasi dan epitelisasi.

Saat pasien kontrol 1 minggu kemudian, berat badan (BB) naik 500 gram dan saat kontrol 3 minggu kemudian, BB naik 100 gram menjadi 10,6 kg. Untuk melengkapi imunisasi, telah diberikan imunisasi hepatitis B, DPT dan polio. Pasien dianjurkan kontrol teratur ke poliklinik IKA RSCM untuk perbaikan status gizi dan pemberian imunisasi berikutnya hingga lengkap.

\section{Diskusi}

Iktiosis lamelar (IL) adalah genodermatosis yang biasanya diturunkan secara resesif autosomal. ${ }^{1,2}$ Autosomal recessive congenital ichthyosis (ARCI) terdiri dari 2 bentuk yaitu Iktiosis lamelar (IL) dan non bullous congenital ichthyosiform erythroderma (NCIE). ${ }^{3,4}$ Sekitar 95\% kasus bayi kolodion akan berlanjut menjadi iktiosis dan sisanya dapat sembuh sempurna (spontaneously healing collodion baby). ${ }^{4}$

Kasus ini jarang ditemukan dengan insidens 1 anak tiap 300.000 kelahiran hidup. Tidak terdapat perbedaan insidens antara laki-laki dan perempuan, tidak ada kecenderungan terhadap etnis tertentu dan insidens meningkat bila terdapat hubungan konsanguinitas. ${ }^{1,2,3}$ Di Departemen Kulit dan Kelamin subbagian Dermatologi Anak FKUI/ RSCM mulai tahun 2001 sampai dengan bulan Mei
2006 didapatkan 18 kasus iktiosis dengan perbandingan 10 kasus (56\%) iktiosis vulgaris (IV), 6 kasus (33\%) IL dan 2 kasus (11\%) NCIE.

Klasifikasi iktiosis umumnya berdasarkan pola pewarisan, berat-ringannya penyakit, klinis dan histopatologi. ${ }^{1}$ Klasifikasi yang sering digunakan adalah berdasarkan pola pewarisan yaitu secara dominan autosomal contohnya iktiosis vulgaris (IV), resesif terangkai X dan resesif autosomal ( IL dan NCIE). ${ }^{2}$ Klasifikasi lain berdasarkan berat ringannya penyakit yaitu bentuk yang ringan (IV), bentuk sedang (IL, NCIE) dan bentuk berat (iktiosis harlequin). ${ }^{7}$

Etiologi penyakit ini disebabkan adanya mutasi gen TGM 1 yang mengkode enzim transglutaminase (TGase 1). ${ }^{1,2}$ Beberapa peneliti menyatakan, mutasi pada IL terjadi pada lokus gen 2q33-35, 14q11.2, 19p12-q12 dan dipengaruhi adanya konsanguinitas. ${ }^{1,8,9}$ Pada NCIE, mutasi terjadi pada lokus gen 3p21, 17p13.1, sedangkan pada tipe intermediat (non lamelar non eritroderma) mutasi terjadi pada lokus gen 19p13.1-p13.2., ${ }^{1,2,8}$ Peneliti lainnya menyatakan mutasi gen ichthyin pada kromosom 5q33.2-q34 juga dapat menyebabkan ARCI. ${ }^{10}$ Untuk memastikan mutasi gen ini, dapat dilakukan analisis kromosom teknik banding., ${ }^{2,9}$ Pada kasus ini pemeriksaan tersebut tidak dilakukan karena masalah biaya, disamping itu hasil pemeriksaan ini tidak mengubah tata laksana pasien maupun prognosis penyakit.

Dalam keadaan normal stratum korneum merupakan produk akhir dari diferensiasi epidermis, komposisi ini terdiri dari korneosit yang kaya protein dan dilingkupi matriks interselular yang kaya lipid. ${ }^{11,12}$ Integritas antara membran sel dan matriks interselular diumpamakan seperti batu bata dan adukan semen (bricks \& mortar) pada suatu bangunan. Lapisan ini berfungsi sebagai penghalang keluarnya cairan tubuh. ${ }^{13,14}$ Adanya mutasi gen TGM 1 yang mengkode enzim TGase 1 menyebabkan gangguan integritas lapisan ini sehingga fungsinya terganggu dan terjadi peningkatan keluarnya cairan tubuh yang berakibat dehidrasi. ${ }^{15,16,17}$ Iktiosis lamelar merupakan kelainan kulit dengan kerusakan kornifikasi yang berat, umumnya bayi lahir kurang bulan dan disertai kelahiran bayi kolodion. ${ }^{1,3,18}$ Pada pasien ini sejak lahir kulit dilapisi membran transparan yang tegang, mengkilat dan mengelupas pada usia 10-14 hari. Pengelupasan tersebut meninggalkan fisura dangkal maupun dalam dan erosi kulit sehingga dapat terjadi invasi kuman serta ketidakseimbangan cairan dan elektrolit. ${ }^{2,3,7}$ 
Secara klinis skuama pada IL tampak kasar, lebar, kecoklatan, generalisata dengan predileksi daerah fleksor dan adanya penebalan pada telapak tangan dan kaki (palmoplantar keratoderma). ${ }^{1,19}$ Kulit kering, retakretak akibat penyumbatan kelenjar keringat. ${ }^{1,2}$ Manifestasi lain pada IL yaitu adanya kelopak mata terangkat keatas (ektropion), mulut berbentuk huruf O (eklabium), distrofi kuku (nail dystrophy), alopesia sikatrik pada daerah berambut (alis dan kepala) serta hipoplasi kartilago nasal dan aurikula. ${ }^{1,2}$

Pada umumnya diagnosis IL dapat ditegakkan secara klinis kecuali pada kasus yang meragukan perlu ditunjang dengan pemeriksaan biopsi kulit. Hasil biopsi didapatkan adanya penebalan nyata pada lapisan korneum (hiperkeratosis) dan lapisan spinosum (akantosis) dengan papilomatosis ringan, sedangkan lapisan granulosum dapat normal atau meningkat (hipergranulosis). Pada daerah dermis didapatkan dilatasi pembuluh darah dan serbukan sel radang limfosit. ${ }^{3,4}$ Hasil biopsi kulit ini hampir sama dengan NCIE, hanya pada NCIE terdapat inti sel yang masih terlihat pada penebalan stratum korneum (parakeratosis) yang luas. Pada kasus ini diagnosis awal IL ditegakkan berdasarkan anamnesis dan manifestasi klinis yaitu adanya riwayat bayi kolodion, ektropion, alopesia sikatrik, hipoplasi kartilago aurikula dan gambaran skuama yang khas kemudian ditunjang hasil biopsi kulit yang sesuai dengan IL.

Diagnosis banding IL adalah NCIE, Netherton syndrome, Sjögren-Larsson syndrome dan trikotiodistrofi. ${ }^{2}$ Iktiosis lamelar sering didiagnosis sebagai NCIE begitu juga sebaliknya. Kedua penyakit ini mempunyai banyak persamaan pada awitan sakit, etiologi, pola pewarisan dan patogenesis tetapi juga mempunyai banyak perbedaan seperti tertera pada Tabel $1 .{ }^{1,2}$

Risiko munculnya keturunan dengan penyakit yang sama dari kedua orangtua karier resesif autosomal $25 \% .{ }^{20}$ Pewarisan resesif autosomal akan menampakkan kelainan (fenotip) ketika alel muncul dalam keadaan homozigot dari kedua orang tua karier yang tampak sehat dan normal. ${ }^{21}$ Pada resesif autosomal biasanya tidak didapatkan penyakit yang serupa dalam 1 - 2 generasi sebelumnya dan konsanguinitas meningkatkan risiko kejadian ini. ${ }^{20,21}$ Pada kasus ini tidak didapatkan konsanguinitas dalam keluarga dan tidak ada anggota keluarga lainnya yang mempunyai gejala seperti ini. Ayah dan ibu diperkirakan karier yang tampak normal sebagai heterozigot dan saat bergabung dapat mewariskan anak dengan fenotip IL.

Tata laksana yang diberikan bersifat suportif yaitu obat-obatan topikal untuk hidrasi kulit berupa emolien yang mengandung bahan keratolitik. Keratolitik bermanfaat untuk mengurangi skuama seperti urea, asam salisilat, propilen glikol, kelompok asam alfahidroksin (asam laktat, asam piruvat dan asam glikolat) dan kombinasi antara bahan-bahan tersebut. ${ }^{1,2,22}$ Pemberian topikal retinoid atau preparat vitamin $\mathrm{D}$ juga cukup efektif. ${ }^{23}$ Penambahan petrolatum atau lanolin pada emolien dapat meningkatkan rasa nyaman pasien. ${ }^{2}$

Risiko efek samping obat (ESO) pada bayi dan anak lebih sering daripada dewasa karena ratio luas permukaan tubuh per berat badannya lebih besar. ${ }^{1,2}$ Pemberian obat topikal perlu diwaspadai, contohnya pemberian asam

Tabel 1. Perbedaan antara iktiosis lamelar dan non bullous congenital ichthyosiform erythroderma (NCIE) ${ }^{1,2}$

\begin{tabular}{|c|c|c|}
\hline & Iktiosis lamellar & NCIE \\
\hline Mutasi lokus gen & $2 \mathrm{q} 33-35,14 \mathrm{q} 11.2,19 \mathrm{p} 12-\mathrm{q} 12$ & $3 \mathrm{p} 21,17 \mathrm{p} 13.2-13.1$ \\
\hline Insidens & $1: 300.000$ & $1: 100.000-200.000$ \\
\hline Manifestasi klinis & $\begin{array}{l}\text { Skuama lebar, tebal, kecoklatan, } \\
\text { generalisata, terutama daerah } \\
\text { fleksor, dengan/ tanpa eritroderma } \\
\text { ringan. }\end{array}$ & $\begin{array}{l}\text { Skuama putih, generalisata dengan } \\
\text { eritroderma yang jelas }\end{array}$ \\
\hline Manifestasi lain & $\begin{array}{l}\text { Alopesia sikatrik, eklabium dan } \\
\text { ektropion. }\end{array}$ & $\begin{array}{l}\text { Jarang ditemukan alopesia sikatrik, } \\
\text { ektropion dan eklabium. }\end{array}$ \\
\hline Histopatologi & $\begin{array}{l}\text { Epidermis: hiperkeratosis, fokal } \\
\text { parakeratosis, papilomatosis ringan, } \\
\text { akantosis. } \\
\text { Dermis : dilatasi pembuluh darah, } \\
\text { serbukan sel radang limfosit }\end{array}$ & $\begin{array}{l}\text { Epidermis: hiperkeratosis, akantosis, } \\
\text { dengan parakeratosis. }\end{array}$ \\
\hline
\end{tabular}


salisilat dapat menyebabkan nausea, tinitus, dispnea dan halusinasi. ${ }^{1}$ Efek samping pemberian topikal retinoid adalah dermatitis toksik yang dikenal "dermatitis retinoid" berupa kemerahan, deskuamasi ringan, nyeri kulit, fotosensitivitas dan komplikasi pada penipisan stratum korneum yang bersifat reversibel tetapi tidak terbukti adanya efek samping sistemik. ${ }^{23}$

Pada iktiosis yang berat (harlequin), retinoid oral sangat bermanfaat sebagai terapi sistemik., ${ }^{2,22}$ Retinoid oral generasi II (etretinat dan asitrenin), pada tingkat selular bekerja menghambat pertumbuhan sel, mengatur diferensiasi dan meningkatkan perlekatan sel sedangkan pada tingkat molekular akan merangsang pembentukan beberapa protein epitelial dan bekerja pada enzim spesifik (kolagenase, ornitin, dekarboksilase). ${ }^{1,23}$ Retinoid juga bermanfaat untuk mencegah komplikasi pada ektropion disamping pemberian tetes mata yang berfungsi sebagai emolien dan lubrikasi mata pada malam hari untuk mencegah terjadinya keratitis akibat paparan. ${ }^{2}$ Obat ini tidak mengembalikan defek biokimia dan struktural herediter sehingga tidak membentuk kulit normal tetapi mencegah ekspresi menifestasi pada kulit. ${ }^{23}$

Komplikasi pada IL terjadi karena adanya gangguan fungsi epidermis yang menyebabkan hilangnya cairan dan panas tubuh. Akibat gangguan tersebut dapat terjadi hipotermi, dehidrasi hipernatremi, sepsis dan toksik terhadap obat topikal. ${ }^{2,22}$ Pada kasus ini, pasien mendapat terapi emolien yang mengandung urea $10 \%$, asam laktat dan asam glikolat dan selama pengobatan tidak didapatkan ESO. Orangtua pasien sudah mengetahui bahwa pengobatan ini diberikan secara kontinyu seumur hidup dan pemberian obat harus hati-hati.

Diagnosis prenatal penting untuk mengetahui kelainan lebih dini yaitu dengan amniosintesis, fetoskopi dan biopsi kulit fetus. Pemeriksaan ini dilakukan pada masa gestasi $20-22$ minggu dan kedua pemeriksaan terakhir beresiko kematian fetus. ${ }^{1,2}$ Dengan semakin pesatnya perkembangan dibidang genetika molekular yaitu pengetahuan tentang mutasi gen yang spesifik sangat penting dalam menentukan terapi yang tepat. Terapi gen merupakan terapi definitif yaitu penyisipan materi genetik ke dalam sel untuk mengoreksi defek atau memodifikasi sifat sel melalui ekspresi gen. ${ }^{5}$ Penyuluhan genetik telah disampaikan kepada orangtua pasien, meskipun didapatkan kesulitan dalam pemahaman masalah. Peyuluhan ini penting untuk menjelaskan kemungkinan terjadi kelainan yang sama pada anak berikutnya.
Iktiosis lamelar merupakan kelainan pada seluruh tubuh dan berlangsung seumur hidup. ${ }^{1,2}$ Tatalaksana memerlukan intervensi beberapa disiplin ilmu seperti Departemen Ilmu Kesehatan Anak, Kulit \& Kelamin, THT, Mata dan Bedah plastik. Pemantauan perkembangan emosi, psikososial dan edukasi bahwa penyakit ini tidak menular sangat perlu. Motivasi pada orangtua penting untuk dapat menerima pasien apa adanya agar anak tidak merasa dikucilkan dan rendah diri sehingga dapat tumbuh dan kembang layaknya anak normal lainnya.

Prognosis ad vitam dan ad functionam pada pasien ini cukup baik, meskipun prognosis ad sanactionam lebih buruk dibandingkan kelopok iktiosis lainnya. Dengan melihat adanya banyak kemajuan pada pasien setelah mendapat pengobatan, diharapkan prognosis pasien dubia ad bonam.

\section{Daftar Pustaka}

1. DiGovanna JJ. Ichthyosiform dermatoses. Dalam: Freedberg IM, Elsen AZ, Wolff K, Austen KF, Goldsmith LA, Katz SI, penyunting. Fitzpatrick's Dermatology in general medicine. Edisi ke-6. New York: McGraw-Hill; 2002.h.481-503.

2. Richard G, Traupe H. Ichthyosis and disorders of cornification. Dalam: Schachner LA, Hansen RC, penyunting. Pediatric dermatology. Edisi ke-3. New York: Churchill livingstone Inc; 2003.h.385-408.

3. Johnson BC, Honig P. Congenital disease (Genodermatoses). Dalam: Elder DE, Elenitsas R, Johnson BL, Murphy GF, penyunting. Lever's Histopathology of the skin. Edisi ke-9. Philadelphia: William \& Wilkins; 2005.h.139-41.

4. Mehregan A, Hasimoto K. Nonneoplastic epithelial and pigmentary disorders Ichthyosiform dermatoses. Dalam: Mehregan A, Hasimoto K, Mehregan DA, Mehregan DR, penyunting. Pinkus' guide to dermatohistopathology. Edisi ke-6. Connecticut: Appleton \& Large; 1995.h.431-9.

5. Esti PK, Widaty S. Terapi gen dan penanggulangannya dalam bidang dermatologi. Media Dermato-Venereol Indones 2004; 31:145-54.

6. Barira S, Boediarja SA, Sugito TL, Wisesa TW, Prihianti S. Epidemiologi genodermatosis di Subbagian Dermatologi Anak Departemen Ilmu Kesehatan Kulit dan Kelamin FKUI/RSUPN Dr. Ciptomangunkusumo Jakarta tahun 2001-2002. Media Dermato-Venereol 
Indones 2004; 31:121-6.

7. Takashi Y, Hideoki O. Clinical and molecular classification of keratinizing disorders. Dalam: Hideoki O, Masaji N, Yasumasa I, penyunting. The Color atlas of "Disorders of keratinization". Tokyo: Kyowa Kikaku Ltd, 2003.h.6-10.

8. Jobard F, Lefevre C, Karaduman A, dkk. Lipoxygenase3 (ALOXE3) and 12(R)-lypoxygenase (ALOX12B) are mutated in non-bullous congenital ichthyosiform erythroderma (NCIE) linked to chromosome 17p.13.1. Hum Mol Genet 2002; 11:107-13.

9. Parmentier L, Lakhdar H, Bardon CB, dkk. Mapping of a second locus for lamellar ichthyosis to chromosome 2q33-35. Hum Mol Genet 1996; 5:555-9.

10. Lefevre C, Bouadjar B, Karaduman A, dkk. Mutations in ichthyin a new gen on chromosome $5 \mathrm{q} 33$ in a new form of autosomal recessive congenital ichthyosis. Hum Mol Genet 2004; 13:2473-82.

11. Darmstadt GL, Sidbury R. Morphology of the skin. Dalam : Behrman RE, Kliegman RM, Jenson GB, penyunting. Nelson textbook of pediatrics. Edisi ke-17. Philadelphia: Saunders; 2004.h.2153-61.

12. Segre JA. Epidermal barrier formation and recovery in skin disorders. J Clin Invest 2006; 116:1150-8.

13. William M. Disorders of cornification. Dalam: Spitz JL, penyunting. Genodermatoses a full-color clinical guide to genetic skin disorder. Baltimore: Williams \& Wilkins, 1996.h.7-11.

14. Paller AS. Disorders of cornification (ichthyosis). Dalam: Eichenfield LF, Frieden IJ, Esterly NB, penyunting. Textbook of neonatal dermatology. Edisi ke-2. Philadelphia: Saunders; 2001.h.276-81.

15. Candi E, Melino G, Lahm A, dkk. Transglutaminase 1 mutation in lamellar ichthyosis. Loss of activity due to failure of activation by proteolitic processing. J Biol Chem 1998; 273:13693-702.

16. Jeon S, Djian P, Green H. Inability of keratinocytes lacking their spesific transglutaminase to from crosslinked enveloped: Absense of envelopes as a simple diagnostic test for lamellar ichthyosis. Proc Natl Acad Sci 1998; 95:687-90.

17. Kuramoto N, Takizawa T, Matsuki M, dkk. Development of ichthyosiform skin compensated for detective permeability barrier function in mice lacking transglutaminase 1. J Clin Invest 2002; 109:243-50.

18. Traupe H. The genetic ichthyosis Dalam: Harper J, Oranje A, Prose N, penyunting. Textbook of pediatric dermatology. Edisi ke-1. Oxford: Blackwell Science Ltd, 2000.h.1107-9.

19. Judge MR. Collodion baby and harlequin ichthyosis. Dalam: Harper J, Oranje A, Prose N, penyunting. Textbook of pediatric dermatology. Edisi ke-1. Oxford: Blackwell Science Ltd; 2000.h.104-6.

20. Hoyme HE. Human genetic. Dalam: Behrman RE, Kliegman RM, Jenson GB, penyunting. Nelson textbook of pediatrics. Edisi ke-17. Philadelphia: Saunders; 2004.h.367-82.

21. Triharsa G. Pola pewarisan genodermatosis. Media Dermato-Venereol Indones 2004; 31:155-65.

22. Guzzo CA, Lazarus GS, Werth VP. Dermatological pharmacology Dalam: Hardman JG, Limbird LE, Molinof PB, dkk, penyunting. Goodman \& Gilman's: the pharmacological basis of therapeutics. Edisi ke-9. New York: McGraw-Hill; 1996.h.1593616.

23. Winanti T, Wasiaatmadja SM, Budimulja U. Pemakaian retinoid di bidang dermatologi. Media DermatoVenereol Indones 1998; 25:95-102.p 